\title{
Hormone concentrations before and after semen-induced ovulation in the bactrian camel (Camelus bactrianus)
}

\author{
Y. S. Xu, H. Y. Wang, G. Q. Zeng, G. T. Jiang and Y. H. Gao* \\ Department of Endocrinology, Institute of Zoology, Academia Sinica, Beijing and *Department of \\ Veterinary Medicine, Gansu Agricultural University, Wuwei, Gansu, People's Republic of China
}

\begin{abstract}
Summary. During the follicular phase of bactrian camels, basal concentrations of LH were $2.7 \pm 1.2 \mathrm{ng} / \mathrm{ml}$. By $4 \mathrm{~h}$ after insemination peak values of $6.9 \pm 1.0 \mathrm{ng} / \mathrm{ml}$ occurred. In addition, a smaller $\mathrm{LH}$ peak $(5.4 \pm 2.5 \mathrm{ng} / \mathrm{ml})$ appeared 1 day before regression of the follicle began in unmated camels. During the follicular phase peripheral plasma progesterone values were low $(0.36 \pm 0.28 \mathrm{ng} / \mathrm{ml})$, but values increased to reach $1.73 \pm 0.74 \mathrm{ng} / \mathrm{ml}$ at 3 days and $2.4 \pm 0.86 \mathrm{ng} / \mathrm{ml}$ at 7 days after ovulation. Plasma oestradiol-17 $\beta$ concentrations were $26.8 \pm 9.0 \mathrm{pg} / \mathrm{ml} \mathrm{during}$ the follicular phase and $30.8 \pm 5.1 \mathrm{pg} / \mathrm{ml}$ when the follicle was maximum size. Values fell after ovulation but rose to $29.8 \pm 6.5 \mathrm{pg} / \mathrm{ml} 3$ days later.
\end{abstract}

\section{Introduction}

It has been shown that camelids are induced ovulators. Instead of oestrous cycles comparable to those of spontaneous ovulators, they exhibit follicular cycles, with follicles developing and regressing successively: it takes $19 \cdot 1 \pm 4 \cdot 25$ days from the start of development of a follicle to the beginning of its regression in bactrian camels (Chen, Yuen, Kang \& Ge, 1980), and ovulation will occur only when mating has taken place. Chen, Yuen, Pan, Huang \& Gao (1983) and Chen, Yuen \& Pan (1985) have demonstrated that ovulation is induced by some component of the seminal plasma.

However, information concerning the hormonal aspects of reproduction in female camels is rare. Abdou, Elwishy, Abdo \& Elsawaf (1971) have investigated the hormonal activities of the placenta of the dromedary (Camelus dromedarius). Elias, Bedrak \& Yagil (1982) have studied the peripheral blood levels of progesterone in female camels during various reproductive cycles. But as far as we are aware, no hormonal data concerning the endocrine events involved in the semeninduced ovulation of the camel are available in the literature. Peripheral plasma concentrations of LH, progesterone and oestradiol-17 $\beta$ have therefore been measured in camels before and after insemination.

\section{Materials and Methods}

\section{Camels and methods}

Thirty female camels 8-15 years of age, and 8 male camels, $4-10$ years of age, were used in the study. They were kept in different herds and grazed freely. Their condition was good; the body weight of the females was about $480 \mathrm{~kg}$ and that of the males was $600 \mathrm{~kg}$. All of them had a sound reproductive history except Male 4 and Female 15. Male 4 was subfertile; of the 24 females inseminated with its semen, only 8 ovulated (Chen et al., 1985). It was used in the present study to investigate the ability of its semen to elicit an LH peak. Female 15 had been infertile for many years; insemination with semen of fertile males did not result in ovulation. It was not included in the experimental groups of the present study, but its response to the semen of fertile male camels was investigated. 
Camel semen samples were collected by means of an artificial vagina as used for cattle, and stored at low temperature $\left(-10^{\circ} \mathrm{C}\right)$.

When the follicles were found maturing in the female camels, a rubber inseminating tube of the type used for horse artificial insemination was inserted gently and as deeply as possible into the vagina, and the materials to be tested were injected through the tube by means of a syringe.

Blood samples were collected from the jugular vein into tubes containing $0.01 \%$ heparin. After centrifugation $(1000 \mathrm{~g})$ for $10 \mathrm{~min}$, the plasma was packaged in ampoules and stored at low temperature $\left(-10^{\circ} \mathrm{C}\right)$ until assay.

The development of follicles and formation of corpora lutea were checked every day, and ovulation was checked by rectal palpation 24,36 and $48 \mathrm{~h}$ after insemination.

\section{Allocation and treatment of female camels}

Eight groups of animals were used in the present study for investigating the plasma concentrations of $\mathrm{LH}$, progesterone and oestradiol- $17 \beta$ at different phases of the follicular cycle and the hormonal changes to the different treatments. The females were allocated to the following treatments.

Group A. Camel semen $1 \cdot 2-4 \cdot 0 \mathrm{ml}$ (the sperm count was about $5-8 \times 10^{8} / \mathrm{ml}$ ) was deposited into the vagina of 7 females. At 1 day and 10 min before insemination, and 4 and $8 \mathrm{~h}$, and 1, 2, 5, 10 and 15 days after insemination, blood samples were taken from the jugular vein.

Group $B$. Three females were mated naturally, and blood samples were collected at the same times as for Group A.

Group $C$. Blood samples were taken 3 times daily from 3 females 10 days after the start of follicular development until the follicles had regressed naturally. The females were not allowed to mate.

Group $D$. Blood samples were taken 3 times daily during the period the follicle was developing in 3 females, but they were not mated.

Group $E$. Three females were inseminated with 5-6 ml semen of Male 4 . The copulatory behaviour and ejaculation characteristics of this male were normal, but most of the females mated by this male did not ovulate (see Chen et al., 1985). Blood samples were taken at 1 day and $10 \mathrm{~min}$ before, and at 4 and $8 \mathrm{~h}$, and 1 and 2 days after insemination.

Group $F$. Three females were mated naturally with Male 4 and blood samples were collected as for Group E females.

Group $G$. Four females were inseminated with $2 \cdot 0-3 \cdot 4 \mathrm{ml}$ goat semen. The sperm count was about $20 \times 10^{8} / \mathrm{ml}$.

Group $H$. Camel semen was centrifuged $(500 \mathrm{~g})$ for $3 \mathrm{~h}$ and the supernatant fluid was decanted; $2 \mathrm{ml}$ saline $(9 \mathrm{~g} \mathrm{NaCl} / \mathrm{l})$ were added to the sediment, and the suspension was agitated and centrifuged again. This was repeated 3 times. The final sperm concentration was $4-7 \times 10^{8} / \mathrm{ml}$ and 4 females were inseminated with $2.5-3.5 \mathrm{ml}$ of these washed spermatozoa. Blood samples were collected as for Group E females.

\section{Hormone assays}

LH. Radioimmunoassay of LH was carried out by the method given by Wang et al. (1979). Dilution of the anti-ovine LH serum was 1:20000; dilution of the second antibody (sheep antirabbit IgG) was $1: 3$. Iodination was carried out by the chloramine-T method (Greenwood, Hunter \& Glover, 1963). The concentration of plasma LH was expressed as ng equivalents of NIH-LH$\mathrm{S} 18 / \mathrm{ml}$. The standard curve ranged from 1.125 to $32.0 \mathrm{ng}$ and the sensitivity was $0 \cdot 1 \mathrm{ng} /$ assay tube. The coefficient of variation (CV) within assays was $5.8 \%(n=100)$, and the CV between assays was $13.38 \%(n=21)$. There was a close correlation between the added and the recovered LH $(y=1.07 x$

$-0 \cdot 13, r=0.999$ ). The purified ovine $\mathrm{LH}$ used for the iodination was a gift from Professor C. H. Li 
(Hormone Research Laboratory, University of California, San Francisco, CA, U.S.A.). Na ${ }^{25}$ I was from Institute of Atomic Energy, Academia Sinica, Beijing. The ovine LH standard was from the NIADDK, National Institutes of Health, MD, U.S.A.

$\mathrm{Xu}$, Wang, De \& Gao (1982) have reported that the patterns of dose-response curves of ovine LH (NIH-LH-S18), plasma of female camel and extracts of female sheep and camel anterior pituitaries were very similar. After logit transformation, the results of covariance analysis for the slopes of these four linear dose-response regressions indicated that there was no significant difference among them. These 4 dose-response curves were statistically parallel. The validity of this $\mathrm{LH}$ radioimmunoassay system in the measurement of camel $\mathrm{LH}$ was further confirmed by the pituitary stimulating test of LHRH in 3 female camels and by the plasma dilution test.

Progesterone. A slight modification of the RIA method described by Furr (1973) was used. This method has been proved to be reliable in the measurement of progesterone of different species, such as sows, cows, ewes and camels (Zeng et al., 1980). The specific activity of $\left[1,2,6,7-{ }^{3} \mathrm{H}\right]$ progesterone was $80 \mathrm{Ci} / \mathrm{mmol}$ (Radiochemical Centre, Amersham, U.K.). Dilution of the antibody (raised in a rabbit) was 1:8000. The standard curve ranged from 25 to $800 \mathrm{pg}$ and the sensitivity was $10 \mathrm{pg} /$ assay tube. The within- and between-assay CVs were $5.7 \%(n=100)$ and $11.9 \%(n=6)$ respectively. The percentage cross-reactions of the antibody (provided by the Department of Endocrinology, Institute of Zoology, Academia Sinica, Code No. 7801) were: progesterone 100, $17 \alpha$-hydroxyprogesterone $0.25,11 \alpha$-hydroxyprogesterone $<50$, androstenedione $<0.02$, testosterone $0 \cdot 13$. Plasma progesterone was extracted with 10 volumes light petroleum and the recovery rate was $93.7 \pm 5 \cdot 1 \%$. Standard progesterone was obtained from Organon Co., Oss, The Netherlands.

Oestradiol-17 $\beta$. A slight modification of the method of Exley, Johnson \& Dean (1971) was used. The specific activity of $\left[2,4,6,7-{ }^{3} \mathrm{H}\right]$ oestradiol was $108 \mathrm{Ci} / \mathrm{mmol}$ (Radiochemical Centre). Dilution of the antibody (raised in a rabbit, from Shanghai Institute of Pharmacology, Code No. 7802) was $1: 6000$. The standard curve ranged from 10 to $200 \mathrm{pg}$, and the sensitivity of the assay was $5 \mathrm{pg} /$ assay tube. The within- and between-assay CVs were $9.8 \%(n=100)$ and $18.6 \%(n=6)$ respectively. The percentage cross-reactions of the antibody were : oestrone 0.03 , oestriol 0.02 . Plasma was extracted with 3.5 volumes anhydrous ether and the recovery rate was $93.4 \pm 2.0 \%$. Standard oestradiol- $17 \beta$ was obtained from Organon.

\section{Results}

In Groups A and B all of the treated females ovulated, but all the females in Groups E, F, G and H, and the females in Group C and D which had not been treated did not. The data obtained for Groups A and B show that the ovulation-inducing effect of the inseminated semen or mating is clearly indicated by an LH surge, while in other groups no LH surge, and consequently no changes in oestradiol and progesterone concentrations, were found. The results for follicular diameter and hormonal concentrations are shown in Text-fig. 1.

\section{$L H$}

During the follicular phase or after regression of the follicle the peripheral plasma LH value was low, $2.7 \pm 1.2 \mathrm{ng} / \mathrm{ml}$ (mean \pm s.d.). The baseline level fluctuated in the course of a day: for example, for Camel 1 the values were $3.6 \pm 1.64 \mathrm{ng} / \mathrm{ml}$ at $08: 00 \mathrm{~h}, 3.04 \pm 1.79 \mathrm{ng} / \mathrm{ml}$ at $12: 00 \mathrm{~h}$ and $2.63 \pm 1.68 \mathrm{ng} / \mathrm{ml}$ at $18: 00 \mathrm{~h}$.

By $4 \mathrm{~h}$ after insemination peripheral $\mathrm{LH}$ rose rapidly to $6.9 \pm 1.0 \mathrm{ng} / \mathrm{ml}$ which was 2.6 times higher than the baseline level; by $8 \mathrm{~h}$ after insemination it had dropped markedly $(<5 \mathrm{ng} / \mathrm{ml})$ and by 1 day after insemination values were similar to those before insemination (Text-fig. 1, Groups $\mathrm{A}$ $\&$ B). Ovulation occurred by 36 or $48 \mathrm{~h}$ and thereafter values remained low. The time of occurrence of the LH peak, the value of LH peak and ovulation time after insemination were identical in 


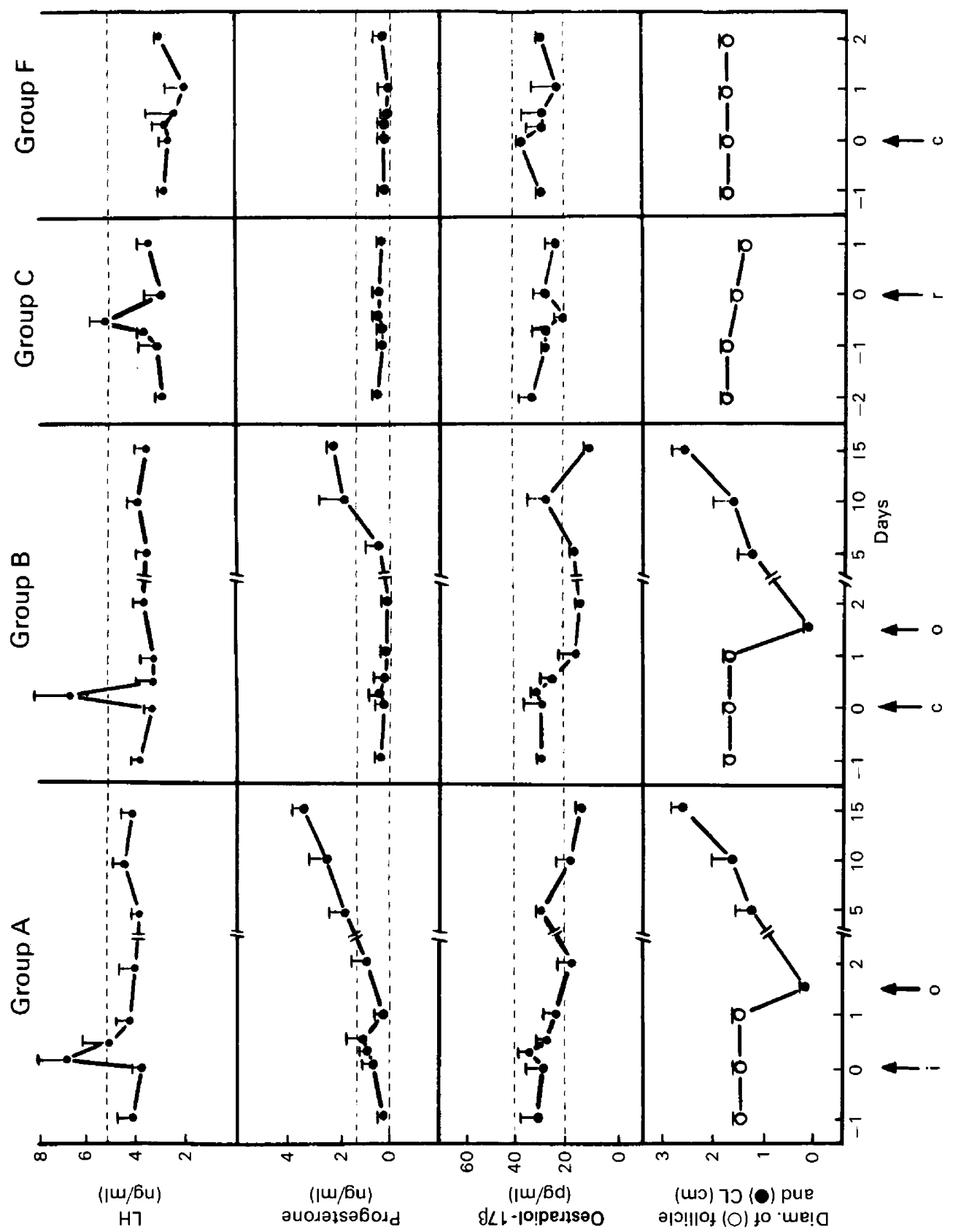


Groups A and B. However, an LH peak was not detected in Groups D, G and H, or in Groups E and $F$ (Text-fig. 1).

In Female 15, which had been infertile for many years, ovulation did not occur after insemination, but an LH peak was detected and was similar to that of normal animals that did ovulate.

In Group C camels a small LH peak $(5 \cdot 4 \pm 2 \cdot 5 \mathrm{ng} / \mathrm{ml})$ appeared 1 day before the follicle started to regress and the value barely exceeded the $95 \%$ upper confidence limit of the LH baseline.

\section{Progesterone}

Plasma concentrations of progesterone were similar in Groups A and B. During the follicular phase values remained low $(0 \cdot 36 \pm 0 \cdot 28 \mathrm{ng} / \mathrm{ml}, n=25)$. After ovulation, when the corpus luteum was forming, the progesterone concentrations rose gradually and were $1.73 \pm 0.74 \mathrm{ng} / \mathrm{ml}(n=7)$ by 3 days and $2.40 \pm 0.86 \mathrm{ng} / \mathrm{ml}(n=7)$ by 7 days after ovulation. Progesterone values remained low in all the other groups.

\section{Oestradiol $-17 \beta$}

The changes in oestradiol concentrations were again similar in Groups A and B. While the follicle was developing the concentration of oestradiol-17ß was $26.8 \pm 9.0 \mathrm{pg} / \mathrm{ml}(n=80)$ in Group A camels, and at maximal follicular size the oestradiol value was $30 \cdot 8 \pm 5 \cdot 1 \mathrm{pg} / \mathrm{ml}(n=28)$. Immediately after ovulation values fell to $19.0 \pm 4.1 \mathrm{pg} / \mathrm{ml}$, but rose again to $29.8 \pm 6.5 \mathrm{pg} / \mathrm{ml}$ 3 days after ovulation. By 13 days after ovulation, when pregnancy had started, the oestradiol concentration had fallen again to $15 \mathrm{pg} / \mathrm{ml}$. Oestradiol concentration in the other groups of camels, in which ovulation did not occur, remained high.

\section{Discussion}

The rabbit has been much studied as a reflexly ovulating animal. Sawyer, Markee \& Hollinshead (1947) found that if the doe was injected with dibenamine within $1 \mathrm{~min}$ after coitus, ovulation could be inhibited. Jones, Bain \& Odell (1976) indicated that LH concentrations started to rise 3 min after coitus, the LH peak appeared within 15 min and ovulation occurred 10-11 h after mating. Jones $e t$ al. (1976) suggested, therefore, that the LH release caused by copulation was probably through one or more neural pathways. However, in the present investigation of bactrian camels, the LH peak only appeared $4 \mathrm{~h}$ after mating or insemination and ovulation did not occur until 30-48 h. The LH release might therefore be evoked through a humoral pathway.

A small LH peak appeared just before the follicle started to regress naturally. This may be caused by a negative feedback effect of oestradiol, the marked falling of oestradiol before regression of the follicle eliciting a sudden rise of $\mathrm{LH}$ through the hypothalamus and pituitary. Nevertheless, this elevation was not sufficient to cause ovulation without the stimulation of semen. This suggests that an LH ovulation threshold may exist and may possibly be $6.0 \mathrm{ng} / \mathrm{ml}$ (Text-fig. 1, Groups A, B \& C). The reason for the refractoriness of Female 15 is unknown; its ovulation threshold might have been higher.

Text-fig. 1. Concentrations of $\mathrm{LH}$, progesterone and oestradiol-17 $\beta$ in peripheral plasma of female camels in Group A ( $N=7$, inseminated with camel semen), Group B $(N=3$, natural mating), Group $\mathrm{C}(\mathrm{N}=3$, follicular regression) and Group $\mathrm{F}(\mathrm{N}=3$, natural mating by Male 4). The broken lines represent the $95 \%$ upper confidence limit for $\mathrm{LH}$, and the $95 \%$ confidence limits for progesterone and oestradiol-17 $\beta$. $i$, insemination; $o$, ovulation; $c$, copulation; $r$, start of follicle regression. 
The oestradiol- $17 \beta$ level in the oestrous female camel is $30 \cdot 3 \pm 2 \cdot 1 \mathrm{pg} / \mathrm{ml}$ before ovulation, and 3 days after ovulation it is still as high as $29.8 \pm 6.5 \mathrm{pg} / \mathrm{ml}$. This is not found in other farm animals and is consistent with the observations of Chen et al. (1980) that the female camel will accept the male for about 5 (2-8) days after ovulation.

We thank the International Foundation for Science for financial assistance (Research Grant No. 595); Professors Z. Y. Zhang and B. X. Chen for organizing this research work; and L. G. Jiang and S. L. De for their help with the assays. The ovine standard NIH-LH-S18 was generously supplied by NIADDK, NIH, U.S.A., the purified LH by Professor C. H. Li (Hormone Research Laboratory, University of California, San Francisco, CA, U.S.A.) and $\mathrm{Na}^{125}$ I by Academia Sinica, Beijing.

\section{References}

Abdou, M.S.S., Elwishy, A.B., Abdo, M.S. \& Elsawaf, S.A. (1971) Hormonal activities of the placenta of the one-humped camel. (Camelus dromedarius). Part I. Gonadotrophic, adrenocorticotrophic and thyrotrophic hormones. J. Anim. Morph. Physiol. 18, 1116.

Chen, B.X., Yuen, Z.X., Kang, C.L. \& Ge, Y.G. (1980) Reproductive pattern of the bactrian camel. I. The sexual activities of the camel. Acta vet. zootech. sin. 11, 65-76. [In Chinese.]

Chen, B.X., Yuen, Z.X., Pan, G.W., Huang, Y.M. \& Gao, Y.H. (I983) Studies on the ovulation mechanism in the bactrian camel. II. The role of semen in induction of ovulation. Acta vet. zootech. sin. 14, 161-166. [In Chinese.]

Chen, B.X., Yuen, Z.X. \& Pan, G.W. (1985) Semeninduced ovulation in the bactrian camel (Camelus bactrianus). J. Reprod. Fert. 74, 335-339.

Elias, E., Bedrak, E. \& Yagil, R. (1982) Peripheral blood levels of progesterone in female camels during various reproductive cycles. J. Steroid Biochem. 17, xci, Abstr.

Exley, D., Johnson, M.W. \& Dean, P.D.G. (1971) Antisera highly specific for $17 \beta$-oestradiol. Steroids. 18, 605-620.

Furr, B.J.A. (1973) Radioimmunoassay of progesterone in peripheral plasma of the domestic fowl in various physiological states and in follicular venous plasma. Acta endocr., Copenh. 72, 89-100.
Greenwood, F.C., Hunter, W.M. \& Glover, J.S. (1963) The preparation of ${ }^{131}$ I-labelled human growth hormone of high specific radioactivity. Biochem. $J$. 89, 114-123.

Jones, E.E., Bain, J.B. \& Odell, W.D. (1976) Postcoital luteinizing hormone release in male and female rabbit as determined by radioimmunoassay. Fert. Steril. 27, 848-852.

Sawyer, C.H., Markee, J.E. \& Hollinshead, W.H. (1947) Inhibition of ovulation in the rabbit by the adrenergic-blocking agent Dibenamine. Endocrinology 41 , 395-402.

Wang, H.Y., Xu, Y.S., Jiang, L.G., De, S.L., Shi, Y.Q. \& Zhou, Z.M. (1979) The effects of sex steroid hormone and gossypol on $\mathrm{LH}$ secretion of rat pituitary by radioimmunoassay. Acta physiol. sin. 31, 337-343. [In Chinese.]

Xu, Y.S., Wang, H.Y., De, S.L. \& Gao, Y.H. (1982) Studies on the ovulation mechanism in bactrian camel. I. Method of radioimmunoassay of LH. Acta vet. zootech. $\sin .13,235-240$. [In Chinese.]

Zeng, G.Q., Jiang, G.T., Wang, H.Y., Xu, Y.S., Zhu, C., Ding, H., Gou, Z.Q. \& Shi, M.Y. (1980) Changes of serum $\mathrm{LH}$, oestradiol and progesterone levels in $\mathrm{Hu}$ yang and Chinese Karakul ewes during the oestrous cycle. Acta vet. zootech. sin. 11, 147-152. [In Chinese.]

Received 22 June 1984 